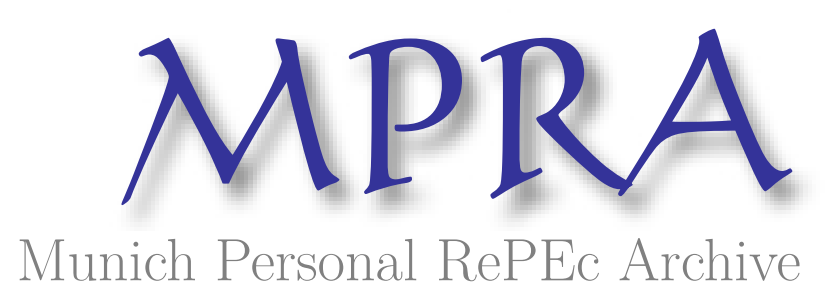

\title{
Trade Openness and Political Distortions
}

\author{
Grechyna, Daryna
}

May 2017

Online at https://mpra.ub.uni-muenchen.de/79951/

MPRA Paper No. 79951, posted 29 Jun 2017 15:22 UTC 


\title{
Trade Openness and Political Distortions
}

\author{
Daryna Grechyna*
}

May, 2017

\begin{abstract}
In this paper we explore the relationship between international trade openness and two major political distortions, political polarization and political instability. We consider the extensive and intensive margins of trade as measured by the number of trade partners and trade volume, respectively. As political distortions and trade characteristics of the country are endogenously related, we instrument political instability by the age difference between the youngest and the oldest effective political leaders of a country and the average neighbors' neighbors political instability. We find that political instability reduces trade openness at the extensive and intensive margin while political polarization negatively affects the extensive margin of trade. We propose a simple model that provides intuition on our findings.
\end{abstract}

Keywords: trade openness; political instability; political polarization; instrumental variables.

JEL Classification Numbers: F10, H10, O24.

*Department of Economics, Middlesex University London, Business School, Hendon Campus, The Burroughs, London NW4 4BT, UK. Tel.: +44 (0)2084115000. E-mail: dgrechna@gmail.com. 


\section{Introduction}

Recent advances in technologies and international cooperation have made the world economy more globalized, resulting in larger trade flows across countries. According to most of the international trade theories, this should have contributed to improved efficiency and higher living standards across the globe through better use of country-specific comparative advantage in production or factor endowments (Ricardo, 1817; Heckscher, 1919; Ohlin, 1933; Balassa, 1963; Davis, 1997), through a rise in consumers utility from larger variety of goods available (Armington, 1969; Dixit and Stiglitz, 1977; Krugman, 1980) and, potentially, through positive spillovers to economic growth (Sachs and Warner, 1995; Frankel and Romer, 1999; Dollar and Kraay, 2003; Noguer and Siscart, 2005). Nevertheless, there remains significant heterogeneity in the degree of countries openness to international trade and country-specific international trade policies. The literature on politics of international trade emphasizes the presence of interest groups as a determinant of cross-industry and within-industry trade protection heterogeneity. ${ }^{1}$ The overall political climate of a country, reflecting the dispersion and strength of such interest groups, can potentially influence the cross-country openness heterogeneity.

In this paper we explore the relationship between international trade openness and overall political climate of a country as measured by two major political distortions, political polarization and political instability. We consider both the extensive and intensive margins of trade as measured by the number of trade partners and trade volume, respectively, as well as the volatility of these variables.

First, we show that higher political polarization combined with political uncertainty results in lower and more volatile trade openness in a simple political economy model of international trade. That occurs because the parties representing groups with different interests regarding the international trade choose different policies (more or less tradeoriented), the formation of international trade links is costly, and the party in power can be replaced by the opposition in the subsequent period. The resulting policy functions are concave in political polarization, leading to the expected openness being decreasing in

\footnotetext{
${ }^{1}$ See Baldwin (1989) and Gawande and Krishna (2003) for review or early work in this area; Mitra (1999), Grossman and Helpman (1994), Magee (2002), Maggi and Rodriguez-Clare (2007) for recent theories of lobbyist-driven protectionist policies; Goldberg and Maggi (1999), Gawande and Bandyopadhyay (2000), Bombardini (2008), and Kim (2017) for examples of empirical analysis.
} 
polarization and political uncertainty. More polarized parties and, subsequently, policies, and higher probability of policy changes lead to higher volatility of trade openness. These results hold for two measures of trade openness: the traditional measure of expenditures on foreign trade as a share to GDP (intensive margin) and the total fraction of international trade links established through the government policy (extensive margin).

Second, we investigate the relationship between political distortions and trade openness in a large cross section of countries. We proxy trade openness using two empirical counterparts to the measures of trade openness applied in the model: the ratio of the sum of exports and imports to the GDP (intensive margin) and the country's degree centrality in the international trade network reflecting the normalized number of country's trading partners (extensive margin). We find that political instability reduces trade openness both at the extensive and intensive margin. For the intensive/extensive trade margin, the effect is more/less profound for developing economies compared to the full sample. Political polarization negatively affects the extensive margin of trade, but less so for developing countries. We also find some evidence that political distortions lead to higher volatility of trade openness.

The evaluation of the causal effect of political distortions on international trade openness is complicated by the fact that both variables can be influenced by the third factor such as the level of economic development or the same fundamental factors. Indeed, Dollar and Kraay (2003) in their analysis of impact of international trade and institutional quality on economic growth found strong correlation between the exogenously instrumented components of trade intensity and institutional quality. We address these issues by using an instrumental variable approach to explain exogenous variation in political distortions. In particular, we use the age difference between the youngest and oldest political leaders in the country and the average political instability of the neighbors' neighbors of a country to instrument for political instability. We employ the World Bank political stability index and the probability of political turnover constructed using Archidos dataset (Goemans et. al, 2009) as two proxies of political instability. The traditional proxies for political polarization include the ethnolinguistic polarization and income inequality (Esteban and Ray, 2011). We use the former measure due to its exogeneity with respect to trade.

The remainder of the paper is as follows. Section 2 presents a two-period model that provides the intuition behind the relationship between political distortions and trade 
openness. Section 3 describes empirical analysis: the data, the methodology, and the estimation results. Section 4 concludes.

\section{The Model}

The aim of the model is to provide intuition on the channels through which political frictions can affect a country's openness to international trade. We propose a simple two-period model combining a version of Armigton "love for variety" international trade model with political frictions in the form of political polarization and political uncertainty.

Consider an open economy inhabited by two types of households, type $i$ and type $j$, each type having measure $1 / 2$, where the type determines the household preferences over domestic versus foreign goods. The households live for two periods, in each of which they decide how to allocate their endowment net of taxes between domestic and foreign consumption. The household of type $h \in\{i, j\}$ utility is given by:

$$
u(h)=\log \left(X_{0}^{1-\mu_{h}} X^{\mu_{h}}\right)
$$

where $X_{0}$ denotes domestic consumption, $X$ denotes aggregate consumption of foreign goods, and $\mu_{h}$ is the weight on foreign goods consumption. The household budget constraint reads as follows:

$$
X_{0}+P X=y(1-\tau)
$$

where $P$ is the foreign price index, $y$ is the period endowment, and $\tau$ is the tax chosen by the government. The foreign consumption aggregator $X$ is defined as follows:

$$
\begin{aligned}
& X=\left(\int_{n} x_{i}^{\rho} d i\right)^{\frac{1}{\rho}}, \rho \in(0 ; 1), n \in[0,1] \\
& \int_{n} p_{i} x_{i} d i=P X
\end{aligned}
$$

where $n$ denotes a fraction of the countries with which the trading links have been established out of the total number of countries in the international trade network, $x_{i}$ is consumption of goods from country $i, \rho$ denotes substitutability between different foreign goods, and $p_{i}$ is the price of $x_{i}$.

The household problem can be solved in two stages: in the first stage, the household decides how to allocate the disposable income between domestic and aggregate foreign consumption to maximize its utility (1) subject to budget constraint (2), and in the second 
stage the household decides on the quantities of foreign goods $x_{i}$ given their prices $p_{i}$, that is, it maximizes (3) subject to (4).

We abstract from the determinants of foreign prices and assume for simplicity that $p_{i}=$ $p$. The solution to the household problem is given by the following optimal allocations:

$$
\begin{aligned}
& X_{0}(h, \tau)=\left(1-\mu_{h}\right) y(1-\tau) \\
& x_{i}(h, \tau)=x(h, \tau)=\frac{P X(h, \tau)}{n p} \\
& X(h, \tau)=\frac{\mu_{h} y(1-\tau)}{P}=n^{\frac{1}{\rho}-1} \frac{\mu_{h} y(1-\tau)}{p} .
\end{aligned}
$$

The household indirect utility results:

$$
u(h, \tau, n)=\log \left(\left(1-\mu_{h}\right)^{1-\mu_{h}} \mu_{h}^{\mu_{h}} p^{-\mu} y\right)+\log (1-\tau)+\mu_{h} \sigma \log n, \sigma=\frac{1-\rho}{\rho} .
$$

In this economy with endowment, $y$, and foreign prices, $p$, exogenously given, the first term in (8) does not depend on the household choices or government policy. The household welfare is a function of the household's type, $h$, and it depends negatively on the tax rate, $\tau$, and positively on the number of links with foreign trade partners, $n$. Next, we consider the problem of the government where the trade-off between $\tau$ and $n$ is introduced.

\section{The government problem}

There are two political parties competing for the place in government. Each party represents one of the households types, $i$ or $j$, that is, each party has its own preferences about international trade reflected in the party-specific weight on foreign goods consumption $\mu_{h}, h \in\{i, j\}$. In particular, we assume that

$$
\mu_{i}=\mu+\Delta, \mu_{j}=\mu-\Delta
$$

that is, party $j$ and households of type $j$ put larger weight on home consumption and therefore are less interested in developing international trade relations as compared to party and households of type $i$. The difference between $\mu_{i}$ and $\mu_{j}$ captured by $\Delta$ represent a measure of political polarization in the society. The party which wins the election chooses the government policy to maximize the utility of its electorate. The government policy consists of setting an income tax $\tau$ the revenues from which are used to finance 
establishment of new trade links with foreign economies. ${ }^{2}$ The process of link formation is costly because it involves negotiations with perspective international partners, installing the transport routes, and adjusting border control and legislation. We assume that the fraction of trading partners and the tax revenues are related as follows:

$$
n_{t}=y \tau_{t}+n_{t-1}
$$

with $n_{0}=0$, so that the economy starts with zero trading partners. The sequence of events in each of the two periods of economy life is as follows: First, the elections take place. The party that wins the elections chooses the optimal tax or, equivalently, the number of trading partners, to maximize the expected utility of its electorate. The new trading links are established. The households consume their optimal allocations, given the income net of taxes and given the available variety of foreign goods, $n$.

In the first period, each party has the same chances of being elected and the party in power takes into account the expectations about the political election result in the next period. In the second period, the incumbent is re-elected with probability $P>0.5$, that is, it enjoys "incumbency advantage" documented in empirical studies (see Azzimonti, 2015 for references and applications). In this setup, $P$ is exogenous (see Azzimonti, 2011 for a microfounded model of $P$ ) and measures political stability in the economy with greater $P$ corresponding to less political uncertainty. Correspondingly, $1-P$ reflect country's political instability. For simplicity and without loss of generality we assume that the inter-temporal discount factor is one.

The problem of the government at the beginning of the economy life can be formulated as follows: ${ }^{3}$

$$
\begin{aligned}
& \max _{\tau_{1}, \tau_{2}} \log \left(1-\tau_{1}\right)+\mu_{h} \sigma \log n_{1}+P\left(\log \left(1-\tau_{2}\right)+\mu_{h} \sigma \log n_{2}\right)+ \\
& (1-P)\left(\log \left(1-\bar{\tau}_{2}\right)+\mu_{h} \sigma \log \bar{n}_{2}\right), \\
& \text { s.t. : } n_{1}=y \tau_{1}, n_{2}=y\left(\tau_{1}+\tau_{2}\right), \bar{n}_{2}=y\left(\tau_{1}+\bar{\tau}_{2}\right), \\
& \bar{\tau}_{2}=\arg \max \left\{\log \left(1-\bar{\tau}_{2}\right)+\mu_{\bar{h}} \sigma \log \bar{n}_{2}, \text { s.t. }: \bar{n}_{2}=y\left(\tau_{1}+\bar{\tau}_{2}\right)\right\},
\end{aligned}
$$

\footnotetext{
${ }^{2}$ The government policy includes decision making over a broad set of variables: government spending, public debt, international relations. Given that the focus of this study is on international trade, we abstract from the remaining fiscal tools and decisions.

${ }^{3}$ The first term in the household indirect utility (8) does not depend on the government choice variables and therefore is omitted in the government problem.
} 
where $h \in i, j, \bar{h}=\neg h$, and $\bar{\tau}_{2}$ and $\bar{n}_{2}$ represent the policy chosen by the opposition party if it is elected in the second period. The problem of the party in power can be solved backwards. The optimal policies are as follows:

$$
\begin{aligned}
& \tau_{1}\left(h_{1}\right)=\frac{\mu_{h_{1}} \sigma+\sqrt{\mu_{h_{1}} \sigma\left(8+9 \mu_{h_{1}} \sigma\right)}}{4+4 \mu_{h_{1}} \sigma}, \\
& \tau_{2}\left(h_{2}, h_{1}\right)=\frac{\mu_{h_{2}} \sigma-\tau_{1}\left(h_{1}\right)}{1+\mu_{h_{2}} \sigma} \\
& n_{1}\left(h_{1}\right)=\tau_{1}\left(h_{1}\right) y \\
& n_{2}\left(h_{2}, h_{1}\right)=\frac{\mu_{h_{2}} \sigma\left(1+\tau_{1}\left(h_{1}\right)\right)}{1+\mu_{h_{2}} \sigma} y
\end{aligned}
$$

where $h_{1}$ and $h_{2}$ are the types of the party in power in the first and second period, respectively.

Given the government policy, we can compute the measures of trade openness in this economy, as follows. The expected connectedness of the country, En, is given by the expected number of trading partners over the economy lifetime:

$$
E n=0.5\left(n_{1}(i)+n_{1}(j)+P\left(n_{2}(i, i)+n_{2}(j, j)\right)+(1-P)\left(n_{2}(i, j)+n_{2}(j, i)\right)\right) .
$$

This measure reflects the country's extensive trade margin.

The expenditures on trade in a given period $t, t e_{t}$, given that the party in power is $h$, is the fraction of spending on foreign goods by type $i$ and type $j$ households, plus spending on investment in new trade links:

$$
\begin{aligned}
& t e_{t}(h)=1-1 / 2 \frac{X_{0}\left(\mu_{i}, \tau_{t}(h)\right)}{y}-1 / 2 \frac{X_{0}\left(\mu_{j}, \tau_{t}(h)\right)}{y}= \\
& 1-0.5\left(2-\mu_{i}-\mu_{j}\right)(1-\tau(h)) .
\end{aligned}
$$

The expected trade expenditures, Ete, is given by the expected fraction of spending on international trade over the economy lifetime which summing up over all possible $t e_{t}(h)$ and simplifying, results in the following expression:

$$
\begin{aligned}
& \text { Ete }=0.5\left(2-0.5\left(2-\mu_{i}-\mu_{j}\right)\left(2-\tau_{1}(i)-\tau_{1}(j)\right)\right)+ \\
& \frac{P}{2}\left(2-0.5\left(2-\mu_{i}-\mu_{j}\right)\left(2-\tau_{2}(i, i)-\tau_{2}(j, j)\right)\right)+ \\
& \frac{1-P}{2}\left(2-0.5\left(2-\mu_{i}-\mu_{j}\right)\left(2-\tau_{2}(i, j)-\tau_{2}(j, i)\right)\right) .
\end{aligned}
$$

This measure reflects the country's intensive trade margin. 


\section{The impact of political frictions}

We can now characterize the impact of political frictions in the form of political polarization, $\Delta$, and political instability, $1-P$, on the levels and volatility of trade openness as measured by (18) and (20). The proofs of Lemma and Propositions in this section are relegated to the Appendix.

Lemma 1. The first period tax rate and the number of trade partners are increasing and concave in the government's weight on foreign consumption: $\frac{d \tau_{1}(h)}{d \mu_{h}}=\frac{d n_{1}(h)}{d \mu_{h}}>0 ; \frac{d^{2} \tau_{1}(h)}{d \mu_{h}^{2}}=$ $\frac{d^{2} n_{1}(h)}{d \mu_{h}^{2}}<0$; the second period tax rate is increasing in the second period government's weight on foreign consumption and decreasing in the first period government's weight on foreign consumption: $\frac{d \tau_{2}\left(h_{2}, h_{1}\right)}{d \mu_{h_{2}}}>0, \frac{d \tau_{2}\left(h_{2}, h_{1}\right)}{d \mu_{h_{1}}}<0$; the second period number of trade partners is increasing in both the first and the second period governments' weight on foreign consumption: $\frac{d n_{2}\left(h_{2}, h_{1}\right)}{d \mu_{h_{1}}}>0, \frac{d n_{2}\left(h_{2}, h_{1}\right)}{d \mu_{h_{2}}}>0$.

The intuition behind Lemma 1 is straightforward: investment in trade links is increasing in the party's in power preferences for foreign consumption. Given that the economy starts with zero trading links, it is optimal to invest heavily in $n$ in the first period and to impose a low tax in the second period, thus achieving certain "consumption smoothing," usually discussed in the literature on fiscal policy.

The next proposition establishes that political frictions in the form of political polarization and political uncertainty lead to lower international trade openness as measured by the expected trade connectedness and expected expenditures on international trade.

Proposition 1. The expected fraction of established international trade links is decreasing in political polarization and political instability. The expected expenditures on international trade are decreasing in political polarization and political uncertainty.

These results are the consequence of the taxes being concave in polarization. Keeping constant the average weight on foreign consumption, more polarized preferences of the competing parties, reflected in larger deviations of their weights on foreign consumption compared to the average, results in lower average expected tax rate, and thus, lower degree of international trade integration. The logarithmic preferences result in the optimal government policies being independent of the political stability, $P$. The expected trade links and expenditures, however, decrease in the political instability because of the same 
concavity argument: lower P leads to lower expected trade integration because of the larger differences between the policies preferred by the competing parties.

We can also characterize the expected volatility of trade openness in the model economy. Given that there are only two periods, the volatility can be measured as the variance of the growth rate of trade openness, measured either by the total expenditures on trade or by the number of trading partners, with the growth rate defined as follows:

$$
g_{\text {op }}\left(h_{2}, h_{1}\right)=\frac{o p_{2}\left(h_{2}, h_{1}\right)-o p_{1}\left(h_{1}\right)}{o p_{1}\left(h_{1}\right)},
$$

where $o p_{t}$ is trade openness in period $t=1,2$ and $o p_{t}=n_{t}$ or $o p_{t}=t e_{t}$, in the case of trade connectedness and trade expenditures measures of trade openness, respectively.

There are two potential sources of exogenous fluctuations in the trade openness in a given country, keeping constant the international conditions such as foreign prices. The sources of fluctuations are output volatility, captured by changes in endowment $y$ and volatility due to political frictions, captured by changes in the type of the party in power, $h$. Given exogenous endowment, the output volatility is independent of political frictions and does not affect the dependence of trade openness volatility on political distortions. Therefore, we assume that $y$ is constant. The volatility of trade openness can be defined as follows:

$$
\begin{aligned}
& V g_{o p}=1 / 2\left(P\left(g_{o p}(i, i)-E g_{o p}\right)^{2}+(1-P)\left(g_{o p}(j, i)-E g_{o p}\right)^{2}+\right. \\
& \left.P\left(g_{o p}(j, j)-E g_{o p}\right)^{2}+(1-P)\left(g_{o p}(i, j)-E g_{o p}\right)^{2}\right)
\end{aligned}
$$

where $E g_{o p}$ denotes the expected growth rate of trade openness defined as follows:

$$
\left.E g_{o p}=\frac{1}{2}\left[P g_{o p}(i, i)+P g_{o p}(j, j)+(1-P) g_{o p}(j, i)+(1-P) g_{o p}(i, j)\right)\right]
$$

We can characterize the relationship between political instability and the volatility of trade openness as follows.

Proposition 2. The volatility of the trade openness measured as a fraction of established international trade links or as total expenditures on international trade is decreasing in political stability.

That is, trade openness is more volatile when political instability is higher. Intuitively, we would also expect the volatility of trade openness to depend positively on political 
polarization. Although we cannot prove this statement formally due to the volatility of trade openness being highly nonlinear in political polarization, our numerical simulations suggest that there is positive relationship between these two variables for a broad set of parameter values.

In the next section, we analyze the relationship between international trade openness and political distortions empirically, and show that a fraction of established international trade partners and trade volume are decreasing in political stability and political polarization, in accordance with the model presented here.

\section{Empirical Evidence}

\subsection{Political Distortions and Levels of Trade Openness}

Our aim is to investigate whether the level and volatility of trade openness depend on political distortions using the data from a cross section of countries. We start with the level of trade openness and estimate the following equation:

$$
O P E N_{i}=\beta_{0}+\beta_{1} P I S_{i}+\beta_{2} P O L A R I Z_{i}+\gamma \mathbf{X}+\epsilon_{i},
$$

where $i$ denotes country, $O P E N$ is the measure of trade openness, $P I S$ is the measure of political instability, and POLARIZ is the measure of political polarization. Each observation is the average value of the corresponding time-series variable over the period 1996-2014. $\mathbf{X}$ is a set of control variables consisting of the fundamental factors which determine trade openness according to the literature: logarithm of population, logarithm of total area in $\mathrm{km}$, latitude, and longitude.

We use two measures of trade openness that characterize the intensive and extensive trade margins and reflect the definitions of trade openness used in the model from the previous section. First, we use the traditional measure of trade openness computed as the ratio of the sum of exports and imports to the GDP; we denote this variable TradeVolume. Second, we proxy trade openness by the country's degree centrality in the international trade network, that is, the number of countries which are the country's trading partners normalized by the total number of countries constituting international trade network. We denote this variable TradeLinks. These two measures reflect different aspects of international trade, the intensive and extensive margins, respectively, and are uncorrelated in 
the data.

Political instability is a broad concept that can refer to the likelihood of riots, revolutions and other forms of violence as well as to the probability of major changes in the government such as those caused by re-elections. We use two measures of political instability to capture the former and the latter definitions. First, we use the inverse of the Political Stability and Absence of Violence/Terrorism index by the World Bank (World Bank Governance Indicators) which measures perceptions of the likelihood of political instability and/or politically motivated violence, including terrorism.

Second, we use Archidos dataset (Goemans et. al, 2009) which contains the information on effective political leaders ${ }^{4}$ for a broad set of countries and a long time span to construct a political instability measure which reflects the political turnover, or probability of major changes in the government. For each country, we compute political turnover as the ratio of the number of regular changes of effective political leader to the total number of changes of effective political leader using the data on political leaders entry and exit during 1970-2014, or shorter period when the earliest available date is after 1970 . The total number of changes of effective leader consists of regular and irregular changes. A loss of office is considered irregular when the leader was removed in contravention of explicit rules and established conventions (Goemans et. al, 2009). We define the regular changes of effective political leader as those done according to the prevailing rules, provisions, conventions and norms of the country or because of natural death or retirement due to poor health.

We denote the political instability measure from the World Bank as PIS_1 and the political turnover measure based on Archidos data as PIS_2. The correlation between these two political instability measures is 0.46 .

The traditional proxies for political polarization include the ethnolinguistic fractionalization and income inequality (Woo, 2009; Esteban and Ray, 2011). The problem with using income inequality as an explanatory variable for international trade openness is its strict endogeneity. In particular, Spilimbergo, et. al (1999) show that income distribution

\footnotetext{
${ }^{4}$ According to Goemans et. al, (2009), effective leader means the person that de facto exercised power in a country. In parliamentary regimes, the Prime Minister is coded as the leader, in presidential systems, the President. In regimes that combine elements of both parliamentary and presidential systems the president is coded as the leader since in these regimes presidents typically control foreign policy. In communist states the Chairman of the Party is generally coded as the effective ruler.
} 
Table 1: Summary Statistics.

\begin{tabular}{|c|c|c|c|c|c|c|c|c|c|c|}
\hline \multirow[b]{2}{*}{ VARIABLES } & \multicolumn{5}{|c|}{ Full Sample } & \multicolumn{5}{|c|}{ Developing Countries } \\
\hline & $\mathrm{N}$ & mean & sd & $\min$ & $\max$ & $\mathrm{N}$ & mean & $\mathrm{sd}$ & $\min$ & $\max$ \\
\hline AGE_DIF & 134 & 23.71 & 10.46 & 0 & 55 & 107 & 24.50 & 10.77 & 0 & 55 \\
\hline TradeVolume & 134 & 79.06 & 33.06 & 7.199 & 184.3 & 107 & 79.20 & 33.18 & 7.199 & 184.3 \\
\hline TradeLinks & 134 & 0.663 & 0.216 & 0.195 & 0.999 & 107 & 0.605 & 0.192 & 0.195 & 0.973 \\
\hline STD_TradeVolume & 134 & 0.123 & 0.198 & 0.0417 & 1.964 & 107 & 0.138 & 0.219 & 0.0423 & 1.964 \\
\hline STD_TradeLinks & 134 & 0.0484 & 0.0270 & 0.00286 & 0.128 & 107 & 0.0546 & 0.0247 & 0.00843 & 0.128 \\
\hline LAREA & 134 & 11.34 & 1.446 & 6.087 & 13.79 & 107 & 11.33 & 1.496 & 6.087 & 13.79 \\
\hline LPOP & 134 & 16.09 & 1.648 & 12.52 & 20.98 & 107 & 16.09 & 1.640 & 12.52 & 20.98 \\
\hline POLARIZ & 134 & 0.446 & 0.260 & 0 & 0.930 & 107 & 0.494 & 0.245 & 0 & 0.930 \\
\hline PIS_1 & 134 & 2.122 & 0.888 & 0.467 & 4.362 & 107 & 2.375 & 0.769 & 0.835 & 4.362 \\
\hline PIS_2 & 134 & 0.153 & 0.216 & 0 & 0.727 & 107 & 0.177 & 0.222 & 0 & 0.727 \\
\hline LATITUDE & 134 & 0.187 & 0.252 & -0.370 & 0.640 & 107 & 0.136 & 0.229 & -0.370 & 0.590 \\
\hline LONGITUDE & 134 & 0.171 & 0.624 & -1.180 & 1.780 & 107 & 0.172 & 0.627 & -0.970 & 1.780 \\
\hline inc_developing & 134 & 0.799 & 0.403 & 0 & 1 & 107 & 1 & 0 & 1 & 1 \\
\hline AVG_NN_PIS_1 & 117 & 1.613 & 0.605 & 0 & 2.652 & 96 & 1.758 & 0.511 & 0 & 2.652 \\
\hline AVG_NN_PIS_2 & 117 & 0.117 & 0.102 & 0 & 0.419 & 96 & 0.132 & 0.0974 & 0 & 0.419 \\
\hline
\end{tabular}

Note: The first five columns report summary statistics for the full sample; the last five columns report summary statistics for developing countries. Data sources: all the data is from the World Bank, except for PIS_2, AVG_NN_PIS_2 - calculated from the data by Goemans et. al, (2009); POLARIZ - from Alesina et al., (2003); and TradeLinks - calculated from the data by Fouquin and Hugot (2016) .

is determined jointly by trade openness and factor endowments. Ethnolinguistic fractionalization is a fundamental factor that can potentially influence both trade openness and political polarization. Given that ethnolinguistic polarization has been considered as the main determinant of political polarization and, under our hypothesis, political polarization is a determinant of international trade openness, we include ethnolinguistic polarization directly as an explanatory variable in the trade openness equation. ${ }^{5}$ We have to keep in mind that its coefficient can reflect the proximate impact of political polarization on trade openness or the impact of ethnolinguistic fractionalization on trade openness. We discuss both interpretations and their relative importance below when we present the results.

The final dataset obtained after removing three outliers for which the trade openness is greater than 250 percent of GDP contains 134 countries, 27 developed and 107 developing. ${ }^{6}$ Summary statistics are reported in Table 1. All the data except for the political instability measure PIS_2, leaders' age difference AGE_DIF, ethnolinguistic fractionalization, and trade network centrality is from the World Bank. We calculate the trade network centrality using the bilateral trade data collected by Fouquin and Hugot (2016). The ethnolinguistic fractionalization data is from Alesina et al., (2003). The variable AGE_DIF is calculated using the data from Goemans et. al, (2009) as discussed below.

\footnotetext{
${ }^{5}$ Thus, for political polarization, we consider a reduced form version of the equation determining trade openness instead of the two-stage least squares because we have more information for ethnolinguistic fractionalization than for political polarization.

${ }^{6}$ All the reported results are robust to inclusion of these outliers.
} 
We expect negative coefficients for political instability and political polarization measures, given our hypothesis that higher political distortions lead to lower levels of trade openness.

Table 2 provides the results of OLS estimation of equation (24). Columns (1)-(5) report the estimates for the full sample of countries and Columns (6)-(10) report the estimates for the sample restricted to developing countries. Political instability has negative association with the measure of intensive margin of trade (trade volume) and this association is more profound for developing economies. For the extensive margin of trade, proxied by the trade network degree centrality, the coefficients of political instability are also negative and significant, but are lower in absolute value for developing countries.

It is a stylized fact that political stability and trade openness increase with the level of economic development. This could lead to more negative coefficients of the political instability measures for developing countries in Table 2. However, in that case we would also expect the coefficients to be more negative for both the intensive and extensive margins of trade. Another possibility is that political instability matters more for trade volume in developing economies compared with developed countries and it matters less for trade links formation in developing economies compared with developed countries. To test these hypotheses we attempt to identify the causal effect of political instability on trade openness as discussed below.

Political polarization proxied by ethnolinguistic fractionalization is insignificant for the trade volume measure of trade openness (intensive margin), and is negative and significant for the network degree centrality measure of trade openness (extensive margin). Ethnolinguistic fractionalization index measures the degree of ethnic, linguistic and religious heterogeneity of population in a country. It is a proxy for political polarization, but it may reflect other aspects of society. This complicates the interpretation due to potentially opposite effects of this variable on trade openness. On the one hand, one may argue that higher ethnolinguistic fractionalization should lead to higher number of trade partners because each ethnic group would want to trade with the country of its ethnic origin to consume its traditional goods. On the other hand, higher ethnolinguistic fractionalization as a cause/proxy of higher political polarization should reduce trade openness due to the reasons outlined in the model from the previous section. The negative and significant coefficient of this variable for the extensive margin of trade suggests that the effect due to 
Table 2: Political distortions and levels of trade openness, OLS estimates

\begin{tabular}{|c|c|c|c|c|c|c|c|c|c|c|}
\hline \multirow{2}{*}{$\begin{array}{l}\text { Dependent: } \\
\text { TradeVolume }\end{array}$} & \multicolumn{5}{|c|}{ Full Sample } & \multicolumn{5}{|c|}{ Developing Countries } \\
\hline & (1) & $(2)$ & (3) & $(4)$ & $(5)$ & $(6)$ & $(7)$ & (8) & (9) & $(10)$ \\
\hline PIS_1 & $\begin{array}{c}-10.54^{* * * *} \\
(2.999)\end{array}$ & & & $\begin{array}{l}-4.208 \\
(3.310)\end{array}$ & & $\begin{array}{c}-16.18^{* * * *} \\
(3.667)\end{array}$ & & & $\begin{array}{l}-8.611^{*} \\
(4.452)\end{array}$ & \\
\hline PIS_2 & & $\begin{array}{l}-18.97 \\
(13.22)\end{array}$ & & & $\begin{array}{l}-21.72^{*} \\
(11.18)\end{array}$ & & $\begin{array}{l}-26.62 * \\
(14.52)\end{array}$ & & & $\begin{array}{c}-26.70^{* *} \\
(11.80)\end{array}$ \\
\hline POLARIZ & & & $\begin{array}{l}-3.559 \\
(11.01)\end{array}$ & $\begin{array}{c}8.108 \\
(10.49)\end{array}$ & $\begin{array}{c}6.738 \\
(10.36)\end{array}$ & & & $\begin{array}{l}-9.336 \\
(12.66)\end{array}$ & $\begin{array}{l}-1.358 \\
(11.49)\end{array}$ & $\begin{array}{l}-5.858 \\
(11.14)\end{array}$ \\
\hline LAREA & & & & $\begin{array}{c}2.130 \\
(1.626)\end{array}$ & $\begin{array}{c}2.360 \\
(1.555)\end{array}$ & & & & $\begin{array}{l}3.742 * * \\
(1.687)\end{array}$ & $\begin{array}{l}4.218^{* *} \\
(1.654)\end{array}$ \\
\hline LPOP & & & & $\begin{array}{c}-10.44^{* * * *} \\
(1.726)\end{array}$ & $\begin{array}{c}-11.43^{* * *} \\
(1.406)\end{array}$ & & & & $\begin{array}{c}-10.10^{* * * *} \\
(2.032)\end{array}$ & $\begin{array}{c}-12.04^{* * * *} \\
(1.481)\end{array}$ \\
\hline LATITUDE & & & & $\begin{array}{l}23.53^{* *} \\
(9.446)\end{array}$ & $\begin{array}{l}23.12^{* *} \\
(9.320)\end{array}$ & & & & $\begin{array}{c}23.04^{* *} \\
(9.940)\end{array}$ & $\begin{array}{l}18.74^{*} \\
(9.791)\end{array}$ \\
\hline LONGITUDE & & & & $\begin{array}{l}7.262^{*} \\
(4.040)\end{array}$ & $\begin{array}{l}7.686^{*} \\
(4.027)\end{array}$ & & & & $\begin{array}{c}9.565^{* *} \\
(4.417)\end{array}$ & $\begin{array}{l}9.986^{* *} \\
(4.555)\end{array}$ \\
\hline Constant & $\begin{array}{c}101.4^{* * * *} \\
(7.024)\end{array}$ & $\begin{array}{c}81.97^{* * * *} \\
(3.472)\end{array}$ & $\begin{array}{c}80.65^{* * * *} \\
(5.414)\end{array}$ & $\begin{array}{c}222.6^{* * * *} \\
(24.43)\end{array}$ & $\begin{array}{c}230.9^{* * * *} \\
(23.53)\end{array}$ & $\begin{array}{c}117.6^{* * * *} \\
(9.047)\end{array}$ & $\begin{array}{c}83.94 * * * \\
(3.972)\end{array}$ & $\begin{array}{c}83.81 * * * \\
(6.550)\end{array}$ & $\begin{array}{c}215.6^{* * * *} \\
(28.68)\end{array}$ & $\begin{array}{c}228.5^{* * *} \\
(27.38)\end{array}$ \\
\hline Observations & 134 & 134 & 134 & 134 & 134 & 107 & 107 & 107 & 107 & 107 \\
\hline R-squared & 0.080 & 0.016 & 0.001 & 0.318 & 0.328 & 0.141 & 0.032 & 0.005 & 0.361 & 0.363 \\
\hline $\begin{array}{l}\text { Dependent: } \\
\text { TradeLinks }\end{array}$ & $(1)$ & $(2)$ & $\begin{array}{l}\text { Full Sample } \\
\text { (3) }\end{array}$ & $(4)$ & $(5)$ & $(6)$ & ${ }^{(7)^{\mathrm{D}}}{ }^{\mathrm{D}}$ & $\begin{array}{c}\text { loping Cou } \\
(8)\end{array}$ & $\begin{array}{r}\text { tries } \\
\\
\end{array}$ & $(10)$ \\
\hline PIS_1 & $\begin{array}{c}-0.0855^{* * *} \\
(0.0197)\end{array}$ & & & $\begin{array}{c}-0.126 * * * \\
(0.0168)\end{array}$ & & $\begin{array}{c}-0.0106 \\
(0.0258)\end{array}$ & & & $\begin{array}{c}-0.0968^{* * *} \\
(0.0213)\end{array}$ & \\
\hline PIS_2 & & $\begin{array}{c}-0.392^{* * * *} \\
(0.0654)\end{array}$ & & & $\begin{array}{c}-0.275 * * * \\
(0.0622)\end{array}$ & & $\begin{array}{c}-0.254^{* * *} \\
(0.0673)\end{array}$ & & & $\begin{array}{c}-0.230^{* * *} \\
(0.0520)\end{array}$ \\
\hline POLARIZ & & & $\begin{array}{c}-0.298^{* * * *} \\
(0.0683)\end{array}$ & $\begin{array}{c}-0.0838^{*} \\
(0.0490)\end{array}$ & $\begin{array}{c}-0.194^{* * * *} \\
(0.0533)\end{array}$ & & & $\begin{array}{l}-0.139^{*} \\
(0.0801)\end{array}$ & $\begin{array}{l}-0.0494 \\
(0.0549)\end{array}$ & $\begin{array}{r}-0.107^{* *} \\
(0.0521)\end{array}$ \\
\hline LAREA & & & & $\begin{array}{c}-0.0108 \\
(0.00901)\end{array}$ & $\begin{array}{c}-0.00279 \\
(0.0100)\end{array}$ & & & & $\begin{array}{l}-0.0126 \\
(0.0101)\end{array}$ & $\begin{array}{r}-0.00769 \\
(0.0104)\end{array}$ \\
\hline LPOP & & & & $\begin{array}{l}0.0970 * * * \\
(0.00839)\end{array}$ & $\begin{array}{l}0.0695 * * * \\
(0.00826)\end{array}$ & & & & $\begin{array}{l}0.0990 * * * \\
(0.00959)\end{array}$ & $\begin{array}{r}0.0774 * * * \\
(0.00828)\end{array}$ \\
\hline LATITUDE & & & & $\begin{array}{c}0.133^{* * *} \\
(0.0479)\end{array}$ & $\begin{array}{l}0.155^{* *} \\
(0.0631)\end{array}$ & & & & $\begin{array}{l}0.111^{* *} \\
(0.0500)\end{array}$ & $\begin{array}{c}0.0685 \\
(0.0598)\end{array}$ \\
\hline LONGITUDE & & & & $\begin{array}{l}-0.0349 \\
(0.0215)\end{array}$ & $\begin{array}{c}-0.0362 \\
(0.0263)\end{array}$ & & & & $\begin{array}{c}-0.0541 * * \\
(0.0217)\end{array}$ & $\begin{array}{c}-0.0514^{* *} \\
(0.0236)\end{array}$ \\
\hline Constant & $\begin{array}{c}0.844^{* * *} * \\
(0.0463)\end{array}$ & $\begin{array}{c}0.723 * * * \\
(0.0225)\end{array}$ & $\begin{array}{c}0.796 * * * \\
(0.0376)\end{array}$ & $\begin{array}{c}-0.490 * * * \\
(0.130)\end{array}$ & $\begin{array}{c}-0.318^{* *} \\
(0.141)\end{array}$ & $\begin{array}{c}0.630 * * * \\
(0.0646)\end{array}$ & $\begin{array}{c}0.650^{* * *} * \\
(0.0238)\end{array}$ & $\begin{array}{c}0.674 * * * \\
(0.0466)\end{array}$ & $\begin{array}{c}-0.597^{* * *} * \\
(0.148)\end{array}$ & $\begin{array}{c}-0.460 * * * \\
(0.152)\end{array}$ \\
\hline Observations & 134 & 134 & 134 & 134 & 134 & 107 & 107 & 107 & 107 & 107 \\
\hline R-squared & 0.124 & 0.156 & 0.128 & 0.655 & 0.534 & 0.002 & 0.088 & 0.032 & 0.560 & 0.520 \\
\hline
\end{tabular}

Note: The first and the last five columns report OLS results for the full sample and for developing countries, respectively. The dependent variable is trade openness measured as the ratio of the sum of exports and imports to the GDP (TradeVolume) and international trade network degree centrality (TradeLinks) in the top and bottom panel, respectively. Robust standard errors in parentheses. *** $\mathrm{p}<0.01, * * \mathrm{p}<0.05, * \mathrm{p}<0.1$.

political frictions dominates. Interestingly, the impact of polarization on intensive margin of trade openness is twice smaller when the sample is restricted to developing countries. A possible explanation of this result could be that the number of factors causing lower trade openness is larger for developing economies, leading to smaller impact of political polarization as compared to the full sample. For example, in developing economy investment climate and institutions are likely to influence international trade more than in developed economies where the capital accumulation and the institutions quality are relatively stable over time. We abstract from these other potential determinants of trade openness in our model due to their endogeneity which could lead to inconsistent results and obscure interpretation.

The coefficients for political instability measures reported in Table 2 may be inconsistent due to potential mutual causality, the fact that political instability and trade openness can be jointly determined by the third variable, and because the political instability 
Table 3: First stage regressions

\begin{tabular}{|c|c|c|c|c|c|c|c|c|}
\hline \multirow[b]{2}{*}{ VARIABLES } & \multicolumn{4}{|c|}{ Full Sample } & \multicolumn{4}{|c|}{ Developing Countries } \\
\hline & $\begin{array}{c}(1) \\
\text { PIS_1 }\end{array}$ & $\begin{array}{c}(2) \\
\text { PIS_1 }\end{array}$ & $\begin{array}{c}\text { (3) } \\
\text { PIS_2 }\end{array}$ & $\begin{array}{c}(4) \\
\text { PIS_2 }\end{array}$ & $\begin{array}{c}(5) \\
\text { PIS_1 }\end{array}$ & $\begin{array}{c}(6) \\
\text { PIS_1 }\end{array}$ & $\begin{array}{c}(7) \\
\text { PIS_2 }\end{array}$ & $\begin{array}{c}(8) \\
\text { PIS_2 }\end{array}$ \\
\hline AGE_DIF & $\begin{array}{c}0.0167^{* *} \\
(0.00724)\end{array}$ & $\begin{array}{c}0.0150^{* *} \\
(0.00639)\end{array}$ & $\begin{array}{c}0.00412 * * \\
(0.00168)\end{array}$ & $\begin{array}{c}0.00420^{* *} \\
(0.00183)\end{array}$ & $\begin{array}{c}0.00940 \\
(0.00743)\end{array}$ & $\begin{array}{c}0.00782 \\
(0.00605)\end{array}$ & $\begin{array}{c}0.00462^{* *} * \\
(0.00190)\end{array}$ & $\begin{array}{c}0.00492^{* *} \\
(0.00209)\end{array}$ \\
\hline AVG_NN_PIS_1 & $\begin{array}{c}0.654^{* * *} \\
(0.129)\end{array}$ & $\begin{array}{c}0.525^{* * *} \\
(0.127)\end{array}$ & & & $\begin{array}{c}0.372^{* *} \\
(0.161)\end{array}$ & $\begin{array}{c}0.325^{* *} \\
(0.139)\end{array}$ & & \\
\hline POLARIZ & & $\begin{array}{c}0.770 * * * \\
(0.291)\end{array}$ & & $\begin{array}{l}-0.0783 \\
(0.0850)\end{array}$ & & $\begin{array}{c}0.791 * * \\
(0.302)\end{array}$ & & $\begin{array}{c}-0.0963 \\
(0.100)\end{array}$ \\
\hline LAREA & & $\begin{array}{l}-0.0655 \\
(0.0549)\end{array}$ & & $\begin{array}{c}-0.000770 \\
(0.0136)\end{array}$ & & $\begin{array}{c}-0.0619 \\
(0.0574)\end{array}$ & & $\begin{array}{c}0.00460 \\
(0.0157)\end{array}$ \\
\hline LPOP & & $\begin{array}{l}0.201^{* * *} \\
(0.0435)\end{array}$ & & $\begin{array}{r}-0.00657 \\
(0.0106)\end{array}$ & & $\begin{array}{c}0.217^{* * *} * \\
(0.0460)\end{array}$ & & $\begin{array}{c}-0.00484 \\
(0.0128)\end{array}$ \\
\hline LATITUDE & & $\begin{array}{l}-0.403 \\
(0.330)\end{array}$ & & $\begin{array}{l}-0.0926 \\
(0.0734)\end{array}$ & & $\begin{array}{c}0.239 \\
(0.344)\end{array}$ & & $\begin{array}{c}-0.104 \\
(0.0900)\end{array}$ \\
\hline LONGITUDE & & $\begin{array}{c}0.100 \\
(0.132)\end{array}$ & & $\begin{array}{c}0.0116 \\
(0.0348)\end{array}$ & & $\begin{array}{c}-0.0243 \\
(0.131)\end{array}$ & & $\begin{array}{c}0.0102 \\
(0.0416)\end{array}$ \\
\hline AVG_NN_PIS_2 & & & $\begin{array}{c}1.195^{* * *} * \\
(0.182)\end{array}$ & $\begin{array}{c}1.236^{* * * *} \\
(0.189)\end{array}$ & & & $\begin{array}{c}1.088^{* * *} \\
(0.219)\end{array}$ & $\begin{array}{c}1.188^{* * * *} \\
(0.208)\end{array}$ \\
\hline Constant & $\begin{array}{c}0.745^{* * *} \\
(0.276)\end{array}$ & $\begin{array}{c}-1.817^{* *} \\
(0.913)\end{array}$ & $\begin{array}{c}-0.0768^{* *} \\
(0.0387)\end{array}$ & $\begin{array}{c}0.0864 \\
(0.262)\end{array}$ & $\begin{array}{c}1.536^{* * *} \\
(0.376)\end{array}$ & $\begin{array}{l}-1.584 \\
(0.960)\end{array}$ & $\begin{array}{c}-0.0756 \\
(0.0511)\end{array}$ & $\begin{array}{c}-0.00777 \\
(0.307)\end{array}$ \\
\hline Obs & 117 & 117 & 117 & 117 & 96 & 96 & 96 & 96 \\
\hline R-squared & 0.256 & 0.429 & 0.330 & 0.342 & 0.075 & 0.297 & 0.245 & 0.261 \\
\hline Cragg-Donald Wald F stat. & 19.608 & 28.451 & 13.434 & 22.429 & 3.761 & 15.329 & 3.339 & 15.000 \\
\hline
\end{tabular}

Note: The first and the last four columns report the First Stage regression results for the full sample and for developing countries, respectively. The dependent variable is political instability PIS_1 or PIS_2. Robust standard errors in parentheses. ${ }^{* * *} \mathrm{p}<0.01,{ }^{* *} \mathrm{p}<0.05,{ }^{*} \mathrm{p}<0.1$.

measures are likely to suffer from measurement errors.

Thus, we need instruments for political instability. The search for valid instruments is complicated by the fact that most of the fundamental factors that influence political polarization also influence trade openness (Dollar and Kraay, 2003). Therefore, standard instruments used in the literature, such as legal origins, geography, settler mortality, or distance from equator, may not capture the independent impact of political polarization on trade openness. One way to proceed could be to use the time series component of the variables of interest and explore the lagged variables as instruments. However, this panel approach requires a number of assumptions on the relationship between the explanatory variables and error terms which are difficult to test and the length of the data is not long enough to ensure that sufficient number of instruments could be used. Moreover, the main variables of interest are quite persistent over time, so exploring their time variation might not be very informative. Therefore, we proceed with the cross section estimation and attempt to employ the instruments that directly influence political instability and are not straightforward determinants of trade openness.

We use the age difference between the youngest and oldest political leaders in a country between 1970-2014 or shorter period, depending on data availability, and the average political instability of the neighbors' neighbors of a country to instrument for political instability. We compute the age of political leader from Archidos dataset (Goemans et. al, 
2009) which reports the data on the year of birth and year on entry to and exit from the office of each political leader. We suggest that higher variability of political leaders' ages observed in a given country can signal higher political instability. The political leader should potentially have appropriate education and sufficient experience in the political area to be able to win the office and to exercise power. High variation in age of the leader implies that the education and/or experience criteria of the leader also vary over time which can influence the political climate in a country. ${ }^{7}$ At the same time, the variation in age should not directly influence country's openness to trade assuming the distribution of preferences over trade volume and the number of trading partners is not age-dependent.

We use the average political instability of the neighbors' neighbors of a country as another instrument for political instability. It has been recognized that geographical neighbors play important role in a country's economic development (see, for example, Ades and Chua, 1997 and Bosker and Garretsen, 2009). In particular, policies conducted in contiguous territories can influence political attitudes in a given country through social links and cultural ties; political instability in the adjacent region may lead to higher government spending for protection of stability in domestic economy; it may also influence the economic growth and international trade, and interfere a country's development path. We suggest that the neighbors' neighbors political instability should not have significant direct influence on a country's economic indicators. For example, the absence of common borders implies that there is no need to change domestic policy in response to escalation in some of the neighbors' neighbor countries. International relations, and trade in particular, with neighbors' neighbors are more likely to be determined by a variety of factors other than geographic closeness. At the same time, the neighbors' neighbors political instability can potentially influence a country's political instability through its impact on this country's neighbors' political climate.

Table 3 shows the first-stage regressions corresponding to the instrumental variable (IV) regressions reported in Table 4. Both instruments of political instability have high predictive power in the full sample with positive coefficients, as expected. When the sample is restricted to developing countries, the age difference of political leaders becomes insignificant for political instability measure by the World Bank. Among the remaining exogenous variables, logarithm of population and ethnolinguistic fractionalization are

\footnotetext{
${ }^{7}$ There are different measures of variation; we use the age difference between the youngest and oldest political leader because it appears to be the strongest instrument.
} 
Table 4: Political distortions and levels of trade openness, IV estimates

\begin{tabular}{|c|c|c|c|c|c|c|c|c|}
\hline \multirow{2}{*}{$\begin{array}{l}\text { Dependent: } \\
\text { TradeVolume }\end{array}$} & \multicolumn{4}{|c|}{ Full Sample } & \multicolumn{4}{|c|}{ Developing Countries } \\
\hline & (1) & (2) & (3) & (4) & (5) & (6) & (7) & (8) \\
\hline PIS_1 & $\begin{array}{c}-15.48^{* *} \\
(7.082)\end{array}$ & & $\begin{array}{c}-23.70^{* * *} \\
(8.628)\end{array}$ & & $\begin{array}{c}-35.83^{* *} \\
(15.57)\end{array}$ & & $\begin{array}{c}-47.50^{* *} \\
(20.54)\end{array}$ & \\
\hline PIS_2 & & $\begin{array}{l}-44.70 \\
(27.27)\end{array}$ & & $\begin{array}{c}-53.46^{* *} \\
(24.35)\end{array}$ & & $\begin{array}{l}-57.20 \\
(36.15)\end{array}$ & & $\begin{array}{l}-45.50 \\
(28.61)\end{array}$ \\
\hline POLARIZ & & & $\begin{array}{c}19.15 \\
(15.46)\end{array}$ & $\begin{array}{c}0.608 \\
(11.11)\end{array}$ & & & $\begin{array}{c}29.28 \\
(24.70)\end{array}$ & $\begin{array}{c}-9.916 \\
(11.56)\end{array}$ \\
\hline LAREA & & & $\begin{array}{c}0.738 \\
(2.132)\end{array}$ & $\begin{array}{c}2.381 \\
(1.866)\end{array}$ & & & $\begin{array}{c}1.434 \\
(2.969)\end{array}$ & $\begin{array}{l}4.384^{* *} \\
(1.987)\end{array}$ \\
\hline LPOP & & & $\begin{array}{c}-7.977^{* * *} \\
(2.602)\end{array}$ & $\begin{array}{c}-12.79 * * * \\
(1.487)\end{array}$ & & & $\begin{array}{l}-2.419 \\
(5.606)\end{array}$ & $\begin{array}{c}-12.51 * * * \\
(1.657)\end{array}$ \\
\hline LATITUDE & & & $\begin{array}{c}2.400 \\
(13.72)\end{array}$ & $\begin{array}{c}13.29 \\
(11.47)\end{array}$ & & & $\begin{array}{c}31.92 \\
(20.13)\end{array}$ & $\begin{array}{c}17.32 \\
(12.05)\end{array}$ \\
\hline LONGITUDE & & & $\begin{array}{l}15.55^{* *} \\
(6.130)\end{array}$ & $\begin{array}{l}12.30^{* *} \\
(5.407)\end{array}$ & & & $\begin{array}{l}11.05 \\
(6.986)\end{array}$ & $\begin{array}{l}10.83^{*} \\
(5.768)\end{array}$ \\
\hline Constant & $\begin{array}{c}112.7 * * * \\
(16.23)\end{array}$ & $\begin{array}{c}85.85^{* * *} \\
(5.457)\end{array}$ & $\begin{array}{c}240.7^{* * *} \\
(36.05)\end{array}$ & $\begin{array}{c}263.4^{* * *} \\
(34.76)\end{array}$ & $\begin{array}{c}164.9^{* * *} \\
(37.59)\end{array}$ & $\begin{array}{c}88.57 * * * \\
(7.389)\end{array}$ & $\begin{array}{c}194.8^{* * *} \\
(61.61)\end{array}$ & $\begin{array}{c}240.0^{* * *} \\
(39.07)\end{array}$ \\
\hline Observations & 117 & 117 & 117 & 117 & 96 & 96 & 96 & 96 \\
\hline Hansen p-value & 0.7215 & 0.4378 & 0.1440 & 0.7349 & 0.8072 & 0.9449 & 0.2492 & 0.5232 \\
\hline Endogeneity p-value & 0.5827 & 0.2863 & 0.0283 & 0.1154 & 0.1315 & 0.2819 & 0.0195 & 0.3045 \\
\hline $\begin{array}{l}\text { Dependent: } \\
\text { TradeLinks } \\
\end{array}$ & $(1)$ & $\begin{array}{l}\text { Full } \\
(2)\end{array}$ & $\begin{array}{l}\text { mple } \\
(3) \\
\end{array}$ & $(4)$ & $(5)$ & $\begin{array}{l}\text { Developin } \\
(6)\end{array}$ & $\begin{array}{c}\text { Countries } \\
(7)\end{array}$ & $(8)$ \\
\hline PIS_1 & $\begin{array}{c}-0.232 * * * \\
(0.0558)\end{array}$ & & $\begin{array}{c}-0.166^{* * *} \\
(0.0429)\end{array}$ & & $\begin{array}{l}-0.184 \\
(0.144)\end{array}$ & & $\begin{array}{l}-0.175^{*} \\
(0.0934)\end{array}$ & \\
\hline PIS_2 & & $\begin{array}{c}-0.734^{* * * *} \\
(0.166)\end{array}$ & & $\begin{array}{c}-0.452^{* * * *} \\
(0.136)\end{array}$ & & $\begin{array}{c}-0.371^{* *} \\
(0.174)\end{array}$ & & $\begin{array}{c}-0.356 * * * \\
(0.135)\end{array}$ \\
\hline POLARIZ & & & $\begin{array}{c}-0.0126 \\
(0.0690)\end{array}$ & $\begin{array}{c}-0.130 * * \\
(0.0579)\end{array}$ & & & $\begin{array}{l}0.0213 \\
(0.108)\end{array}$ & $\begin{array}{l}-0.104^{*} \\
(0.0592)\end{array}$ \\
\hline LAREA & & & $\begin{array}{r}-0.00877 \\
(0.0117)\end{array}$ & $\begin{array}{l}0.00206 \\
(0.0120)\end{array}$ & & & $\begin{array}{c}-0.00756 \\
(0.0139)\end{array}$ & $\begin{array}{c}0.00394 \\
(0.0115)\end{array}$ \\
\hline LPOP & & & $\begin{array}{c}0.108^{* * *} \\
(0.0139)\end{array}$ & $\begin{array}{c}0.0733^{* * *} * \\
(0.00945)\end{array}$ & & & $\begin{array}{c}0.117 * * * \\
(0.0254)\end{array}$ & $\begin{array}{c}0.0807^{* * * *} \\
(0.00949)\end{array}$ \\
\hline LATITUDE & & & $\begin{array}{c}0.169^{* * *} \\
(0.0650)\end{array}$ & $\begin{array}{c}0.235^{* * *} * \\
(0.0622)\end{array}$ & & & $\begin{array}{c}0.173^{* * *} \\
(0.0545)\end{array}$ & $\begin{array}{c}0.114^{*} \\
(0.0660)\end{array}$ \\
\hline LONGITUDE & & & $\begin{array}{l}-0.0516^{*} \\
(0.0285)\end{array}$ & $\begin{array}{c}-0.0706 * * \\
(0.0300)\end{array}$ & & & $\begin{array}{c}-0.0690^{* *} \\
(0.0297)\end{array}$ & $\begin{array}{c}-0.0683^{* *} \\
(0.0299)\end{array}$ \\
\hline Constant & $\begin{array}{c}1.171^{* * *} \\
(0.118)\end{array}$ & $\begin{array}{c}0.779 * * * \\
(0.0306)\end{array}$ & $\begin{array}{l}-0.646^{* * *} \\
(0.197)\end{array}$ & $\begin{array}{c}-0.461^{* *} \\
(0.199)\end{array}$ & $\begin{array}{c}1.052^{* * *} \\
(0.346)\end{array}$ & $\begin{array}{c}0.673^{* * *} \\
(0.0362)\end{array}$ & $\begin{array}{c}-0.814^{* * * *} \\
(0.266)\end{array}$ & $\begin{array}{c}-0.639 * * * \\
(0.191)\end{array}$ \\
\hline Obs & 117 & 117 & 117 & 117 & 96 & 96 & 96 & 96 \\
\hline Hansen p-value & 0.1035 & 0.5096 & 0.3947 & 0.7889 & 0.2243 & 0.2074 & 0.6053 & 0.555 \\
\hline Endogeneity p-value & 0.0025 & 0.0011 & 0.1548 & 0.0230 & 0.1074 & 0.1472 & 0.3423 & 0.1585 \\
\hline
\end{tabular}

Note: The first and the last four columns report IV results for the full sample and for developing countries, respectively. The dependent variable is trade openness measured as the ratio of the sum of exports and imports to the GDP (TradeVolume) and international trade network degree centrality (TradeLinks) in the top and bottom panel, respectively. Robust standard errors in parentheses. ${ }^{* * *}$ $\mathrm{p}<0.01,{ }^{* *} \mathrm{p}<0.05,{ }^{*} \mathrm{p}<0.1$. 
significant determinants of political instability measure by the World Bank (Columns (2)-(3), (8)-(9)), but insignificant for the political turnover measure (Columns (5)-(6), (11)-(12)). The Cragg-Donald Wald test results, reported in Table 3, suggest rejection of the weak instrument hypothesis for the full sample. For the sample of countries restricted to developing economies, the test suggests that there is some evidence that the instruments are weak. Nevetheless, we report the IV results both for the full and for the restricted sample, for completeness.

The 2SLS IV estimates reported in Table 4 yield negative and significant coefficients for both political instability variables. ${ }^{8}$ The results of the Hansen test suggest that we cannot reject the hypothesis that the instruments are valid. The coefficients are larger in absolute value than their OLS counterparts. One possible reason for this discrepancy is the measurement errors in the political instability variables which result in the OLS estimates biased towards zero. We apply the endogeneity test to gain some insight into consistency of the OLS estimates. The results are mixed: For the TradeVolume measure of trade openness, we cannot reject the null hypothesis that the political instability measures are exogenous, which implies that the corresponding OLS estimates are more efficient. For the TradeLinks measure of trade openness, the political instability measures are endogenous in the full sample, suggesting that the OLS estimates are inconsistent.

In qualitative terms, the pattern of the IV and OLS estimates is the same: The impact of political instability on the intensive/extensive trade margin is more/less profound in developing countries as compared to the full sample. We can conjecture that political instability matters more for trade openness in developing countries, although the weakness of the instruments for developing economies casts doubts on the validity of this conjecture.

Overall, the estimation results suggest that higher political distortions lead to lower levels of trade openness. Political instability has negative impact on both the extensive and intensive trade margins. Higher political polarization negatively influences the extensive trade margin.

Next, we analyze the relationship between the political distortions and the volatility of trade openness.

\footnotetext{
${ }^{8}$ We apply the 2SLS estimator because of the relatively small sample size. The GMM estimation yields very similar results.
} 
Table 5: Political distortions and volatility of trade openness, OLS estimates

\begin{tabular}{|c|c|c|c|c|c|c|c|c|c|c|}
\hline \multirow{2}{*}{$\begin{array}{l}\text { Dependent: } \\
\text { STD_TradeVolume }\end{array}$} & \multicolumn{5}{|c|}{ Full Sample } & \multicolumn{5}{|c|}{ Developing Countries } \\
\hline & (1) & (2) & (3) & (4) & (5) & (6) & (7) & (8) & (9) & (10) \\
\hline PIS_1 & $\begin{array}{c}0.0728^{* *} \\
(0.0361)\end{array}$ & & & $\begin{array}{l}0.0813^{*} \\
(0.0470)\end{array}$ & & $\begin{array}{l}0.0882^{*} \\
(0.0519)\end{array}$ & & & $\begin{array}{c}0.0989 \\
(0.0626)\end{array}$ & \\
\hline PIS_2 & & $\begin{array}{c}0.0871 * * * \\
(0.0301)\end{array}$ & & & $\begin{array}{c}0.0678^{* *} \\
(0.0296)\end{array}$ & & $\begin{array}{c}0.0669 * * \\
(0.0322)\end{array}$ & & & $\begin{array}{l}0.0586^{*} \\
(0.0309)\end{array}$ \\
\hline POLARIZ & & & $\begin{array}{l}0.0710^{* * * *} \\
(0.0270)\end{array}$ & $\begin{array}{l}-0.0229 \\
(0.0655)\end{array}$ & $\begin{array}{c}0.0684 * * * \\
(0.0243)\end{array}$ & & & $\begin{array}{c}0.0395 \\
(0.0444)\end{array}$ & $\begin{array}{l}-0.0328 \\
(0.0782)\end{array}$ & $\begin{array}{c}0.0428 \\
(0.0366)\end{array}$ \\
\hline LAREA & & & & $\begin{array}{c}0.00916 \\
(0.00842)\end{array}$ & $\begin{array}{c}0.00370 \\
(0.00913)\end{array}$ & & & & $\begin{array}{c}0.00916 \\
(0.00987)\end{array}$ & $\begin{array}{c}0.00506 \\
(0.00986)\end{array}$ \\
\hline LPOP & & & & $\begin{array}{l}-0.00912^{*} \\
(0.00540)\end{array}$ & $\begin{array}{c}0.00802 \\
(0.00769)\end{array}$ & & & & $\begin{array}{l}-0.0137 \\
(0.00855)\end{array}$ & $\begin{array}{c}0.00821 \\
(0.00914)\end{array}$ \\
\hline LATITUDE & & & & $\begin{array}{c}0.0387 \\
(0.0488)\end{array}$ & $\begin{array}{c}0.0149 \\
(0.0347)\end{array}$ & & & & $\begin{array}{l}0.0238 \\
(0.0460)\end{array}$ & $\begin{array}{l}0.0545 \\
(0.0595)\end{array}$ \\
\hline LONGITUDE & & & & $\begin{array}{c}0.0215 \\
(0.0165)\end{array}$ & $\begin{array}{c}0.0263 \\
(0.0185)\end{array}$ & & & & $\begin{array}{c}0.0241 \\
(0.0199)\end{array}$ & $\begin{array}{l}0.0263 \\
(0.0201)\end{array}$ \\
\hline Constant & $\begin{array}{l}-0.0314 \\
(0.0618)\end{array}$ & $\begin{array}{c}0.110^{* * *} \\
(0.0163)\end{array}$ & $\begin{array}{c}0.0915 * * * \\
(0.0231)\end{array}$ & $\begin{array}{c}-0.00706 \\
(0.111)\end{array}$ & $\begin{array}{l}-0.0960 \\
(0.126)\end{array}$ & $\begin{array}{l}-0.0710 \\
(0.105)\end{array}$ & $\begin{array}{c}0.127^{* * *} * \\
(0.0219)\end{array}$ & $\begin{array}{c}0.119^{* * *} \\
(0.0383)\end{array}$ & $\begin{array}{l}0.0283 \\
(0.134)\end{array}$ & $\begin{array}{l}-0.0945 \\
(0.147)\end{array}$ \\
\hline Observations & 134 & 134 & 134 & 134 & 134 & 107 & 107 & 107 & 107 & 107 \\
\hline R-squared & 0.107 & 0.009 & 0.009 & 0.120 & 0.030 & 0.096 & 0.005 & 0.002 & 0.110 & 0.026 \\
\hline $\begin{array}{l}\text { Dependent: } \\
\text { STD_TradeLinks }\end{array}$ & (1) & $(2)$ & $\begin{array}{l}\text { Full Sample } \\
\text { (3) }\end{array}$ & $(4)$ & $(5)$ & (6) & $(7)^{\text {Dev }}$ & $\begin{array}{l}\text { oping Coun } \\
\text { (8) }\end{array}$ & (9) & (10) \\
\hline PIS_1 & $\begin{array}{c}0.00338 \\
(0.00246)\end{array}$ & & & $\begin{array}{l}0.00566^{* *} \\
(0.00272)\end{array}$ & & $\begin{array}{c}-0.00705^{* *} \\
(0.00273)\end{array}$ & & & $\begin{array}{l}-0.00409 \\
(0.00347)\end{array}$ & \\
\hline PIS_2 & & $\begin{array}{l}0.0198 * * \\
(0.00985)\end{array}$ & & & $\begin{array}{c}0.0140 \\
(0.0104)\end{array}$ & & $\begin{array}{l}0.00243 \\
(0.0106)\end{array}$ & & & $\begin{array}{l}0.00381 \\
(0.0110)\end{array}$ \\
\hline POLARIZ & & & $\begin{array}{c}0.0113 \\
(0.00805)\end{array}$ & $\begin{array}{l}-0.00432 \\
(0.00847)\end{array}$ & $\begin{array}{l}0.000322 \\
(0.00827)\end{array}$ & & & $\begin{array}{l}-0.00923 \\
(0.00847)\end{array}$ & $\begin{array}{l}-0.00811 \\
(0.00903)\end{array}$ & $\begin{array}{l}-0.0118 \\
(0.00878)\end{array}$ \\
\hline LAREA & & & & $\begin{array}{c}-0.000474 \\
(0.00163)\end{array}$ & $\begin{array}{r}-0.000828 \\
(0.00156)\end{array}$ & & & & $\begin{array}{r}-0.000601 \\
(0.00172)\end{array}$ & $\begin{array}{r}-0.000466 \\
(0.00173)\end{array}$ \\
\hline LPOP & & & & $\begin{array}{c}-0.00484^{* * *} \\
(0.00176)\end{array}$ & $\begin{array}{c}-0.00360^{* *} \\
(0.00151)\end{array}$ & & & & $\begin{array}{l}-0.00182 \\
(0.00216)\end{array}$ & $\begin{array}{l}-0.00271 \\
(0.00181)\end{array}$ \\
\hline LATITUDE & & & & $\begin{array}{c}-0.0240^{* *} \\
(0.0110)\end{array}$ & $\begin{array}{c}-0.0248^{* *} \\
(0.0109)\end{array}$ & & & & $\begin{array}{l}-0.0118 \\
(0.0114)\end{array}$ & $\begin{array}{l}-0.0126 \\
(0.0120)\end{array}$ \\
\hline LONGITUDE & & & & $\begin{array}{l}-0.00242 \\
(0.00382)\end{array}$ & $\begin{array}{l}-0.00242 \\
(0.00388)\end{array}$ & & & & $\begin{array}{l}-0.00256 \\
(0.00403)\end{array}$ & $\begin{array}{l}-0.00283 \\
(0.00402)\end{array}$ \\
\hline Constant & $\begin{array}{c}0.0412^{* * *} \\
(0.00637)\end{array}$ & $\begin{array}{c}0.0453^{* * *} \\
(0.00310)\end{array}$ & $\begin{array}{c}0.0433 * * * \\
(0.00468)\end{array}$ & $\begin{array}{l}0.127^{* * *} \\
(0.0263)\end{array}$ & $\begin{array}{l}0.118 * * * \\
(0.0261)\end{array}$ & $\begin{array}{c}0.0713 * * * \\
(0.00764)\end{array}$ & $\begin{array}{c}0.0542 * * * \\
(0.00333)\end{array}$ & $\begin{array}{l}0.0592 * * * \\
(0.00508)\end{array}$ & $\begin{array}{l}0.106 * * * \\
(0.0291)\end{array}$ & $\begin{array}{c}0.111^{* * *} \\
(0.0299)\end{array}$ \\
\hline Obs & 134 & 134 & 134 & 134 & 134 & 107 & 107 & 107 & 107 & 107 \\
\hline $\mathrm{R}$-squared & 0.012 & 0.026 & 0.012 & 0.161 & 0.148 & 0.048 & 0.000 & 0.008 & 0.086 & 0.075 \\
\hline
\end{tabular}

Note: The first and the last five columns report OLS results for the full sample and for developing countries, respectively. The dependent variable is the volatility of trade openness measured as the standard deviation of the growth of the ratio of the sum of exports and imports to the GDP (STD_TradeVolume) and as the standard deviation of the growth of international trade network degree centrality (STD_TradeLinks) in the top and bottom panel, respectively. Robust standard errors in parentheses. ${ }^{* * *} \mathrm{p}<0.01,{ }^{* *} \mathrm{p}<0.05,{ }^{*} \mathrm{p}<0.1$.

\subsection{Political Distortions and Volatility of Trade Openness}

For the volatility of trade openness, we estimate the following equation:

$$
S D O P E N_{i}=\beta_{0}+\beta_{1} P I S_{i}+\beta_{2} P_{O L A R I Z}+\gamma \mathbf{X}+\epsilon_{i},
$$

where the dependent variable, SDOPEN is the standard deviation of the growth rate of the trade openness, measured as the sum of exports and imports over GDP or the trade network degree centrality, and calculated over the period 1996-2014. The explanatory variables are the same as in (24). We expect positive coefficients for political instability and political polarization measures, given our hypothesis that higher political distortions lead to higher volatility of trade openness.

Table 5 reports the OLS estimates of equation (25) and Table 6 reports the corresponding IV estimates. The OLS results feature positive and significant coefficients for 
Table 6: Political distortions and volatility of trade openness, IV estimates

\begin{tabular}{|c|c|c|c|c|c|c|c|c|}
\hline \multirow{2}{*}{$\begin{array}{l}\text { Dependent: } \\
\text { STD_TradeVolume }\end{array}$} & \multicolumn{4}{|c|}{ Full Sample } & \multicolumn{4}{|c|}{ Developing Countries } \\
\hline & (1) & $(2)$ & (3) & (4) & (5) & (6) & (7) & (8) \\
\hline PIS_1 & $\begin{array}{c}0.0530^{* * * *} \\
(0.0205)\end{array}$ & & $\begin{array}{c}0.0435 \\
(0.0361)\end{array}$ & & $\begin{array}{c}0.0465 \\
(0.0496)\end{array}$ & & $\begin{array}{c}0.0297 \\
(0.0679)\end{array}$ & \\
\hline PIS_2 & & $\begin{array}{l}0.176^{* *} \\
(0.0830)\end{array}$ & & $\begin{array}{c}0.119 \\
(0.109)\end{array}$ & & $\begin{array}{c}0.107 \\
(0.111)\end{array}$ & & $\begin{array}{l}0.0620 \\
(0.121)\end{array}$ \\
\hline POLARIZ & & & $\begin{array}{c}0.0168 \\
(0.0577)\end{array}$ & $\begin{array}{c}0.0476 \\
(0.0403)\end{array}$ & & & $\begin{array}{c}0.0176 \\
(0.0824)\end{array}$ & $\begin{array}{c}0.0387 \\
(0.0475)\end{array}$ \\
\hline LAREA & & & $\begin{array}{c}0.00742 \\
(0.00968)\end{array}$ & $\begin{array}{l}0.00458 \\
(0.0115)\end{array}$ & & & $\begin{array}{l}0.00743 \\
(0.0104)\end{array}$ & $\begin{array}{l}0.00547 \\
(0.0137)\end{array}$ \\
\hline LPOP & & & $\begin{array}{l}-0.000571 \\
(0.00752)\end{array}$ & $\begin{array}{c}0.00842 \\
(0.00823)\end{array}$ & & & $\begin{array}{l}0.00234 \\
(0.0159)\end{array}$ & $\begin{array}{c}0.00856 \\
(0.00917)\end{array}$ \\
\hline LATITUDE & & & $\begin{array}{l}0.0130 \\
(0.0507)\end{array}$ & $\begin{array}{c}-0.00449 \\
(0.0398)\end{array}$ & & & $\begin{array}{c}0.0373 \\
(0.0518)\end{array}$ & $\begin{array}{c}0.0473 \\
(0.0589)\end{array}$ \\
\hline LONGITUDE & & & $\begin{array}{c}0.0360 \\
(0.0286)\end{array}$ & $\begin{array}{l}0.0410 \\
(0.0288)\end{array}$ & & & $\begin{array}{c}0.0349 \\
(0.0248)\end{array}$ & $\begin{array}{c}0.0348 \\
(0.0250)\end{array}$ \\
\hline Constant & $\begin{array}{c}0.0120 \\
(0.0369)\end{array}$ & $\begin{array}{l}0.100 * * * \\
(0.0186)\end{array}$ & $\begin{array}{c}-0.0579 \\
(0.171)\end{array}$ & $\begin{array}{l}-0.106 \\
(0.161)\end{array}$ & $\begin{array}{l}0.0304 \\
(0.119)\end{array}$ & $\begin{array}{l}0.124^{* * *} \\
(0.0310)\end{array}$ & $\begin{array}{l}-0.0716 \\
(0.233)\end{array}$ & $\begin{array}{l}-0.102 \\
(0.195)\end{array}$ \\
\hline Obs & 117 & 117 & 117 & 117 & 96 & 96 & 96 & 96 \\
\hline Hansen p-value & 0.1678 & 0.2409 & 0.1874 & 0.2830 & 0.1859 & 0.1734 & 0.2100 & 0.1952 \\
\hline Endogeneity p-value & 0.9187 & 0.0763 & 0.8067 & 0.3915 & 0.7038 & 0.1290 & 0.9304 & 0.5059 \\
\hline $\begin{array}{l}\text { Dependent: } \\
\text { STD_TradeLinks }\end{array}$ & $(1)$ & $(2)^{\mathrm{Ful}}$ & $\begin{array}{r}\text { Sample } \\
(3)\end{array}$ & $(4)$ & (5) & $\begin{array}{l}\text { Developin } \\
(6)\end{array}$ & $\begin{array}{c}\text { Countries } \\
(7)\end{array}$ & (8) \\
\hline PIS_1 & $\begin{array}{l}0.0134^{* *} \\
(0.00675)\end{array}$ & & $\begin{array}{c}0.0105 \\
(0.00707)\end{array}$ & & $\begin{array}{l}-0.0125 \\
(0.0137)\end{array}$ & & $\begin{array}{r}-0.00993 \\
(0.0162)\end{array}$ & \\
\hline PIS_2 & & $\begin{array}{c}0.0363^{* *} \\
(0.0176)\end{array}$ & & $\begin{array}{l}0.0296 * \\
(0.0169)\end{array}$ & & $\begin{array}{l}-0.0176 \\
(0.0209)\end{array}$ & & $\begin{array}{c}-0.00364 \\
(0.0196)\end{array}$ \\
\hline POLARIZ & & & $\begin{array}{l}-0.0157 \\
(0.0121)\end{array}$ & $\begin{array}{l}-0.00834 \\
(0.00960)\end{array}$ & & & $\begin{array}{c}-0.00463 \\
(0.0173)\end{array}$ & $\begin{array}{c}-0.0134 \\
(0.00964)\end{array}$ \\
\hline LAREA & & & $\begin{array}{c}0.000104 \\
(0.00171)\end{array}$ & $\begin{array}{c}-0.000576 \\
(0.00169)\end{array}$ & & & $\begin{array}{c}-0.000239 \\
(0.00183)\end{array}$ & $\begin{array}{l}0.000358 \\
(0.00165)\end{array}$ \\
\hline LPOP & & & $\begin{array}{c}-0.00605^{* * *} \\
(0.00210)\end{array}$ & $\begin{array}{c}-0.00387^{* * *} \\
(0.00167)\end{array}$ & & & $\begin{array}{r}-0.000672 \\
(0.00394)\end{array}$ & $\begin{array}{l}-0.00280 \\
(0.00196)\end{array}$ \\
\hline LATITUDE & & & $\begin{array}{c}-0.0293^{* *} \\
(0.0126)\end{array}$ & $\begin{array}{c}-0.0334^{* * * *} \\
(0.0119)\end{array}$ & & & $\begin{array}{c}-0.00653 \\
(0.0139)\end{array}$ & $\begin{array}{r}-0.00942 \\
(0.0123)\end{array}$ \\
\hline LONGITUDE & & & $\begin{array}{l}7.50 \mathrm{e}-05 \\
(0.00463)\end{array}$ & $\begin{array}{c}0.00124 \\
(0.00457)\end{array}$ & & & $\begin{array}{l}-0.00346 \\
(0.00505)\end{array}$ & $\begin{array}{l}-0.00355 \\
(0.00502)\end{array}$ \\
\hline Constant & $\begin{array}{c}0.0185 \\
(0.0151)\end{array}$ & $\begin{array}{l}0.0422 * * * \\
(0.00416)\end{array}$ & $\begin{array}{c}0.135 * * * \\
(0.0341)\end{array}$ & $\begin{array}{c}0.123 * * * \\
(0.0360)\end{array}$ & $\begin{array}{c}0.0842^{* *} \\
(0.0340)\end{array}$ & $\begin{array}{c}0.0571 * * * \\
(0.00498)\end{array}$ & $\begin{array}{c}0.0954 * * \\
(0.0376)\end{array}$ & $\begin{array}{c}0.105 * * * \\
(0.0354)\end{array}$ \\
\hline Obs & 117 & 117 & 117 & 117 & 96 & 96 & 96 & 96 \\
\hline Hansen p-value & 0.4940 & 0.8610 & 0.6110 & 0.8827 & 0.8440 & 0.7209 & 0.5910 & 0.3873 \\
\hline Endogeneity p-value & 0.1267 & 0.2939 & 0.4677 & 0.3079 & 0.5567 & 0.2503 & 0.5465 & 0.6080 \\
\hline
\end{tabular}

Note: The first and the last four columns report IV results for the full sample and for developing countries, respectively. The dependent variable is the volatility of trade openness measured as the standard deviation of the growth of the ratio of the sum of exports and imports to the GDP

(STD_TradeVolume) and as the standard deviation of the growth of international trade network degree centrality (STD_TradeLinks) in the top and bottom panel, respectively. Robust standard errors in parentheses. ${ }^{* * *} \mathrm{p}<0.01,{ }^{* *} \mathrm{p}<0.05,{ }^{*} \mathrm{p}<0.1$. 
political instability in the full sample. Political polarization positively and significantly influences the volatility of trade volume but is insignificant for the volatility of trade network degree centrality. In the IV estimates, the measure of political turnover is still significant for the extensive trade margin but the other coefficients of political distortions become insignificant once the fundamental factors such as logarithm of population or geographical position captured by latitude are added to the equation. However, the endogeneity test suggests that we cannot reject the null hypothesis that political instability is exogenous, for all variants of the model estimated. Therefore, the OLS estimates are more efficient. For the sample restricted to developing countries, the political distortions have insignificant coefficients. Thus, our results suggest that political frictions do not have a primary importance for fluctuations of trade openness in developing countries but in general higher political instability increases the volatility of trade openness.

\section{Conclusions}

This paper investigated the relationship between trade openness and political distortions in the form of political instability and political polarization. We aimed to explore the exogenous variation in the political frictions to evaluate their causal effect on trade openness. In doing so, we found that political distortions lead to lower trade openness, both at the extensive and intensive trade margin. Moreover, we found some evidence that higher political distortions lead to higher volatility of trade openness. We provided a theoretical foundations on the negative impact of political distortions on trade using a standard model of international trade combined with political frictions. Our findings suggest that policies aimed at improving the political climate of a country can be beneficial for international trade, both in terms of trade volume and in terms of the number of country's trading partners.

\section{References}

[1] Ades, A. and Chua, H.B., 1997. Thy neighbor's curse: regional instability and economic growth. Journal of Economic Growth, 2(3), pp.279-304.

[2] Alesina, A., Devleeschauwer, A., Easterly, W., Kurlat, S., and Wacziarg, R., 2003. Fractionalization. Journal of Economic Growth, 8 , 155-194. 
[3] Armington, Paul S., 1969. A Theory of Demand for Products Distinguished by Place of Production. IMF Staff Papers 16 (1), pp. 159178.

[4] Azzimonti, M. 2011. Barriers to investment in polarized societies. The American Economic Review, 101(5): 2182-2204.

[5] Azzimonti, M., 2015. The dynamics of public investment under persistent electoral advantage. Review of Economic Dynamics, 18(3), pp.653-678.

[6] Balassa, B., 1963. An empirical demonstration of classical comparative cost theory. The Review of Economics and Statistics, pp.231-238.

[7] Baldwin, Robert E., 1989. The Political Economy of Trade Policy. Journal of Economic Perspectives, 3(4): 119-135.

[8] Bombardini, M., 2008. Firm heterogeneity and lobby participation. Journal of International Economics, 75(2), pp.329-348.

[9] Bosker, M. and Garretsen, H., 2009. Economic development and the geography of institutions. Journal of economic geography, 9(3), pp.295-328.

[10] Davis, D.R., 1997. Critical evidence on comparative advantage? North-North trade in a multilateral world. Journal of Political Economy, 105(5), pp.1051-1060.

[11] Dixit, A.K. and Stiglitz, J.E., 1977. Monopolistic competition and optimum product diversity. The American Economic Review, 67(3), pp.297-308.

[12] Dollar, D., and Kraay, A., 2003. Institutions, Trade, and Growth, Journal of Monetary Economics, 50, 133-62.

[13] Esteban, J. and Ray, D., 2011. Linking conflict to inequality and polarization. The American Economic Review, 101(4), 1345-1374.

[14] Fouquin, M. and Hugot, J., 2016. Two Centuries of Bilateral Trade and Gravity Data: 1827-2014. CEPII Working Paper, N2016-14, mai 2016.

[15] Frankel, J. A., and Romer, D., 1999. Does Trade Cause Growth?, American Economic Review, 89(3), 379-399. 
[16] Gawande, K. and Bandyopadhyay, U., 2000. Is protection for sale? Evidence on the Grossman-Helpman theory of endogenous protection. Review of Economics and statistics, 82(1), pp.139-152.

[17] Gawande, K. and Krishna, P., 2003. The political economy of trade policy: Empirical approaches. Handbook of international trade, 1, pp.139-152.

[18] Goemans, H.E., Gleditsch, K.S. and Chiozza, G., 2009. Introducing Archigos: A dataset of political leaders. Journal of Peace research, 46(2), pp.269-283.

[19] Goldberg, P. and G. Maggi, 1999. Protection for Sale: An Empirical Investigation, American Economic Review, 89, 1135-1155.

[20] Grossman, G. M. and E. Helpman, 1994. Protection for Sale, American Economic Review, 84(4), 833-850.

[21] Heckscher, Eli. 1919. The Effect of Foreign Trade on the Distribution of Income. Ekonomisk Tidskrift 21: 497-512.

[22] Kim, I.S., 2017. Political cleavages within industry: firm-level lobbying for trade liberalization. American Political Science Review, 111(1), pp.1-20.

[23] Krugman, P., 1980. Scale economies, product differentiation, and the pattern of trade. The American Economic Review, 70(5), pp.950-959.

[24] Magee, C., 2002. Endogenous trade policy and lobby formation: an application to the free-rider problem. Journal of International Economics, 57(2), pp.449-471.

[25] Maggi, G. and Rodriguez-Clare, A., 2007. A political-economy theory of trade agreements. The American Economic Review, 97(4), pp.1374-1406.

[26] Mitra, D., 1999. Endogenous lobby formation and endogenous protection: a long-run model of trade policy determination. American Economic Review, pp.1116-1134.

[27] Noguer, M. and Siscart, M., 2005. Trade raises income: a precise and robust result. Journal of international Economics, 65(2), pp.447-460.

[28] Ohlin, Bertil. 1933. Interregional and International Trade. Cambridge, MA: Harvard University Press. 
[29] Ricardo, D., 1817. Principles of political economy and taxation. London: J. Murray

[30] Sachs, J. D., and Warner, A. M., 1995. Economic Reform and the Process of Global Integration, Brookings Papers on Economic Activity, 1, 1-95.

[31] Spilimbergo, A., Londoo, J.L. and Szkely, M., 1999. Income distribution, factor endowments, and trade openness. Journal of development Economics, 59(1), pp.77-101.

[32] Woo, J., 2009. Why do more polarized countries run more procyclical fiscal policy?. The Review of Economics and Statistics, 91(4), pp.850-870. 


\section{Appendix}

Proof of Lemma 1. The results obtain by taking the derivatives of (14)-(17) with respect to $\mu_{h_{1}}$ and $\mu_{h_{2}}$ and simplifying:

$$
\begin{gathered}
\frac{d \tau_{1}\left(h_{1}\right)}{d \mu_{h_{1}}}=\frac{d n_{1}\left(h_{1}\right)}{d \mu_{h_{1}}}=\frac{\sigma\left(5 \mu_{h_{1}} \sigma+\sqrt{\mu_{h_{1}} \sigma\left(9 \mu_{h_{1}} \sigma+8\right)}+4\right)}{4\left(\mu_{h_{1}} \sigma+1\right)^{2} \sqrt{\mu_{h_{1}} \sigma\left(9 \mu_{h_{1}} \sigma+8\right)}}>0 . \\
\frac{d^{2} \tau_{1}\left(h_{1}\right)}{d \mu_{h_{1}}^{2}}=\frac{d^{2} n_{1}\left(h_{1}\right)}{d \mu_{h_{1}}^{2}}=-\frac{\sigma^{2}\left(\mu _ { h _ { 1 } } \sigma \left(8\left(\sqrt{\mu_{h_{1}} \sigma\left(9 \mu_{h_{1}} \sigma+8\right)}+6\right)+\right.\right.}{2\left(\mu_{h_{1}} \sigma+1\right)^{3}\left(\mu_{h_{1}} \sigma\left(9 \mu_{h_{1}} \sigma+8\right)\right)^{3 / 2}} \\
\frac{\left.\left.3 \mu_{h_{1}} \sigma\left(15 \mu_{h_{1}} \sigma+3 \sqrt{\mu_{h_{1}} \sigma\left(9 \mu_{h_{1}} \sigma+8\right)}+28\right)\right)+8\right)}{2\left(\mu_{h_{1}} \sigma+1\right)^{3}\left(\mu_{h_{1}} \sigma\left(9 \mu_{h_{1}} \sigma+8\right)\right)^{3 / 2}}<0 . \\
\frac{d \tau_{2}\left(h_{2}, h_{1}\right)}{d \mu_{h_{2}}}=\frac{\sigma+\tau_{1}\left(h_{1}\right)}{\left(1+\mu_{h_{2}} \sigma\right)^{2}}>0, \frac{d \tau_{2}\left(h_{2}, h_{1}\right)}{d \mu_{h_{1}}}=-\frac{1}{1+\mu_{h_{2}} \sigma}<0 . \\
\frac{d n_{2}\left(h_{2}, h_{1}\right)}{d \mu_{h_{2}}}=\frac{\sigma\left(1+\tau_{1}\left(h_{1}\right)\right)}{\left(1+\mu_{h_{2}} \sigma\right)^{2}}>0, \frac{d n_{2}\left(h_{2}, h_{1}\right)}{d \mu_{h_{1}}}=\frac{\mu_{h_{2}}}{1+\mu_{h_{2}} \sigma}>0 .
\end{gathered}
$$

Proof of Proposition 1. First, we show that $\frac{d E n}{d \Delta}<0$ and $\frac{d E n}{d P}>0$. From Lemma 1, $\frac{d n_{1}(h)}{d \mu_{h}}>0, \frac{d n_{1}(i)}{d \mu_{i}}<\frac{d n_{1}(j)}{d \mu_{j}}$, given that $\mu_{i}>\mu_{j}$ from (9). This implies that

$$
\frac{d\left(n_{1}(i)+n_{1}(j)\right)}{d \Delta}=\frac{d n_{1}(i)}{d \mu_{i}}-\frac{d n_{1}(j)}{d \mu_{j}}<0 .
$$

Consider now the derivative of $n_{2}(i, i)+n_{2}(j, j)$, that is, the second sum in (18), with respect to $\Delta$ :

$$
\begin{aligned}
& \frac{d\left(n_{2}(i, i)+n_{2}(j, j)\right)}{d \Delta}=\frac{\sigma\left(1+\tau_{1}(i)\right)+\mu_{i} \sigma\left(1+\mu_{i} \sigma\right) \frac{d \tau_{1}(i)}{d \mu_{i}}}{\left(1+\mu_{i} \sigma\right)^{2}}- \\
& \frac{\sigma\left(1+\tau_{1}(j)\right)+\mu_{j} \sigma\left(1+\mu_{j} \sigma\right) \frac{d \tau_{1}(j)}{d \mu_{j}}}{\left(1+\mu_{j} \sigma\right)^{2}}=4\left[\frac{d \tau_{1}(i)}{d \mu_{i}} \tau(i)-\frac{d \tau_{1}(j)}{d \mu_{j}} \tau(j)\right]<0,
\end{aligned}
$$

because

$$
\frac{d\left(\frac{d \tau_{1}\left(h_{1}\right)}{d \mu_{h_{1}}} \tau_{1}\left(h_{1}\right)\right)}{d \mu_{h_{1}}}=\frac{d^{2} \tau_{1}\left(h_{1}\right)}{d \mu_{h_{1}}^{2}} \tau_{1}\left(h_{1}\right)-\left(\frac{d \tau_{1}\left(h_{1}\right)}{d \mu_{h_{1}}}\right)^{2}<0 .
$$

Consider now the derivative of the last sum in (18):

$$
\begin{aligned}
\frac{d\left(n_{2}(j, i)+n_{2}(i, j)\right)}{d \Delta}=\sigma & \frac{(1+\tau(j))\left(1+\mu_{j} \sigma\right)^{2}-\left(1+\tau_{1}(i)\right)\left(1+\mu_{i} \sigma\right)^{2}}{\left(1+\mu_{i} \sigma\right)^{2}\left(1+\mu_{j} \sigma\right)^{2}}+ \\
& +\frac{\left.\left(\mu_{j}+\mu_{i} \mu_{j} \sigma\right) \frac{d \tau_{1}(i)}{d \mu_{i}}-\left(\mu_{i}+\mu_{i} \mu_{j} \sigma\right) \frac{d \tau_{1}(j)}{d \mu_{j}}\right)}{\left(1+\mu_{i} \sigma\right)\left(1+\mu_{j} \sigma\right)}<0
\end{aligned}
$$


given that $\mu_{i}>\mu_{j}, \frac{d \tau_{1} h_{1}}{d \mu_{h_{1}}}>0$, and $\frac{d^{2} \tau_{1} \mu_{h_{1}}}{d \mu_{h_{1}}^{2}}<0$.

Consider the derivative of $E n$ with respect to $P$ :

$$
\frac{d E n}{d P}=n_{2}(i, i)+n_{2}(j, j)-n_{2}(i, j)-n_{2}(j, i)=\frac{\left(\tau_{1}(i)-\tau_{1}(j)\right)\left(\mu_{i}-\mu_{j}\right) \sigma}{\left(1+\mu_{i} \sigma\right)\left(1+\mu_{j} \sigma\right)}>0 .
$$

The expected number of established trade links is increasing in $P$ and thus, decreasing in political uncertainty.

Second, we show that $\frac{d E t e}{d \Delta}<0$ and $\frac{d E t e}{d P}>0$. The expected expenditures on trade defined in (20) can be re-written as follows:

$$
\begin{aligned}
& \text { Ete }=\bar{C}+0.5\left(1-0.5\left(\mu_{i}+\mu_{j}\right)\right)\left[\tau_{1}(i)+\tau_{1}(j)+\right. \\
& \left.P\left(\tau_{2}(i, i)+\tau_{2}(j, j)\right)+(1-P)\left(\tau_{2}(j, i)+\tau_{2}(i, j)\right)\right],
\end{aligned}
$$

where $\bar{C}$ does not depend on polarization. Consider the derivative of the above expression with respect to $\Delta$ :

$$
\begin{aligned}
& \frac{\text { Ete }}{d \Delta}=\left(1-0.5\left(\mu_{i}+\mu_{j}\right)\right)\left(\frac{d \tau_{1}(i)}{d \mu_{i}}-\frac{d \tau_{1}(j)}{d \mu_{j}}+\right. \\
& P\left(\frac{\left.\sigma\left(1+\tau_{1}(i)\right)-\frac{d \tau_{1}(i)}{d \mu_{i}}\right)\left(1+\mu_{i} \sigma\right)}{\left(1+\mu_{i} \sigma\right)^{2}}+\frac{-\sigma\left(1+\tau_{1}(j)\right)+\frac{d \tau_{1}(j)}{d \mu_{j}}\left(1+\mu_{j} \sigma\right)}{\left(1+\mu_{j} \sigma\right)^{2}}\right)+ \\
& \left.(1-P)\left(\frac{-\sigma\left(1+\tau_{1}(i)\right)-\frac{d \tau_{1}(i)}{d \mu_{i}}\left(1+\mu_{j} \sigma\right)}{\left(1+\mu_{j} \sigma\right)^{2}}+\frac{\sigma\left(1+\tau_{1}(j)\right)+\frac{d \tau_{1}(j)}{d \mu_{j}}\left(1+\mu_{i} \sigma\right)}{\left(1+\mu_{i} \sigma\right)^{2}}\right)\right)= \\
& \left(1-0.5\left(\mu_{i}+\mu_{j}\right)\right) \times \\
& \left(\frac{P\left(\sigma(1+\tau(i))+\mu_{i} \sigma\left(1+\mu_{i} \sigma\right) \frac{d \tau_{1}(i)}{d \mu_{i}}\right)}{\left(1+\mu_{i} \sigma\right)^{2}}-\frac{P\left(\sigma(1+\tau(j))+\mu_{j} \sigma\left(1+\mu_{j} \sigma\right) \frac{d \tau_{1}(j)}{d \mu_{j}}\right)}{\left(1+\mu_{j} \sigma\right)^{2}}+\right. \\
& \left.\frac{(1-P)\left(\mu_{j} \sigma \frac{d \tau_{1}(i)}{d \mu_{i}}-\sigma\left(1+\tau_{1}(i)\right)\right)}{\left(1+\mu_{j} \sigma\right)}+\frac{(1-P)\left(-\mu_{i} \sigma \frac{d \tau_{1}(j)}{d \mu_{j}}+\sigma\left(1+\tau_{1}(j)\right)\right)}{\left(1+\mu_{i} \sigma\right)}\right)<0
\end{aligned}
$$

where the line before the last is negative as in (31) and the last line is negative because $\frac{d \tau_{1}(i)}{d \mu_{i}}>0, \frac{d^{2} \tau_{1}(i)}{d \mu_{i}^{2}}<0$, and $\mu_{i}>\mu_{j}$. To show that expected expenditures on trade are decreasing in political uncertainty, consider the derivative of Ete with respect to $P$ :

$$
\begin{aligned}
& \frac{\text { Ete }}{d P}=0.5\left(2-\mu_{i}-\mu_{j}\right)\left(\tau_{2}(i, i)-\tau_{2}(i, j)+\tau_{2}(j, j)-\tau_{2}(j, i)\right)= \\
& 0.5\left(2-\mu_{i}-\mu_{j}\right) \frac{\sigma\left(\mu_{i}-\mu_{j}\right)\left(\tau_{1}(i)-\tau_{1}(j)\right)}{\left(1+\mu_{i} \sigma\right)\left(1+\mu_{j} \sigma\right)}>0 .
\end{aligned}
$$

\section{Proof of Proposition 2.}


The derivative of $V g_{o p}$ with respect to $P$ when trade openness is measured by the number of trading partners is given by:

$$
\begin{aligned}
& -\frac{\left(\mu_{i}-\mu_{j}\right) \sigma^{2} y_{2}^{2}\left(\tau_{1}(i)-\tau_{1}(j)\right)}{2\left(1+\mu_{i} \sigma\right)^{2}\left(1+\mu_{j} \sigma\right)^{2} y_{1}^{2} \tau_{1}(i)^{2} \tau_{1}(j)^{2}} \times \\
& \left(\left(\mu_{i}(1-P)+\mu_{j} P+\mu_{i} \mu_{j} \sigma\right) \tau_{1}(j)+\tau_{1}(i)\left(\mu_{j}(1-P)+\mu_{i} P+\right.\right. \\
& \left.\left.\mu_{i} \mu_{j} \sigma+\left(\mu_{i}+\mu_{j}+2 \mu_{i} \mu_{j} \sigma\right) \tau_{1}(j)\right)\right)<0
\end{aligned}
$$

so that the volatility of trade openness measured by the number of trading partners is increasing in political instability.

The derivative of $V g_{o p}$ with respect to $P$ when trade openness is measured by the expenditure on international trade is given by:

$$
\begin{aligned}
& -\frac{\Delta(\mu-1)^{2} \sigma\left(\tau_{1}(i)-\tau_{1}(j)\right)}{(1-\Delta \sigma+\mu \sigma)^{2}(1+(\Delta+\mu) \sigma)^{2}\left(\mu-(\mu-1) \tau_{1}(j)\right)^{2}\left(\mu-(\mu-1) \tau_{1}(i)\right)^{2}} \\
& {\left[2 \mu\left(\left(\mu^{2}-\Delta^{2}\right) \sigma^{2}+2 \mu+\mu \sigma+2 \mu^{2} \sigma\right)\left(1-(1-1 / \mu) \tau_{1}(i) \tau_{1}(j)\right)+\right.} \\
& \left.2 \mu+\left(\mu+2 \mu^{2}+\Delta(1-2 \mu)^{2}(2 P-1)\right) \sigma+\mu_{i} \mu_{j} \sigma^{2}\right) \tau_{1}(i)+ \\
& \tau_{1}(j)\left(2 \mu+\left(\mu+2 \mu^{2}-\Delta(1-2 \mu)^{2}(2 P-1)\right) \sigma+\mu_{i} \mu_{j} \sigma^{2}\right]<0 .
\end{aligned}
$$

so that the volatility of trade openness measured by the expenditure on international trade is increasing in political instability. 